\title{
An Interdisciplinary Application Based on Constructivist Approach: Teaching of Energy Topics
}

\author{
Güliz AYDIN* Ali Günay Balım**
}

\begin{abstract}
In this study, the effects of constructivist approach and traditional approach on students' understanding of "The Work, Power, Energy and Simple Machines" topics were studied. It was studied whether there was a statistically significant difference in cognitive and affective level between the experimental group to whom constructivist approach was applied, and the control group to whom traditional approach was applied in the learning of energy topics with interdisciplinary quality. The research was based on pre-test - posttest quasi-experimental design with control group. Participants were $687^{\text {th }}$ grade students. The research was done on the second term of 2004-2005 education year. Before and after the study, the students were given science attitude scale and "The Work, Power, Energy and Simple Machines" achievement test. According to the pre-tests, there wasn't a statistically significant difference between the science achievement and attitudes of the students, but after the study it was determined that there were statistically significant differences on the cognitive and affective levels in favor of the experiment group.
\end{abstract}

Key Words: Constructivist approach, interdisciplinary learning, energy concept

\footnotetext{
* Science Teacher

** Assist.Prof.Dr., Dokuz Eylül University, agunay.balim@deu.edu.tr
} 


\section{SUMMARY}

The past educational approach that consider students as empty containers which should be filled with knowledge has been replaced by the educational approach in which active participation of students in the process of learning is believed to be necessary and students are held responsible for their own learning (Tonbul, 2001: 16). Therefore, it is believed that methods which are in compliance with the constructivist learning approach that enables students to learn much better by way of constructing their own knowledge, should be used.

This paper is on the interdisciplinary teaching which takes the constructivist approach as a base. In this study activities which would involve the active participation of students were prepared and students were expected to configure knowledge by way of making use of their own mental skills. Interdisciplinary teaching can be defined as "the coherent presentation of the disciplinary fields that are joined together around specific concepts or subjects" (Yıldırım, 1996). According to Gürdal, Şahin and Bayram (1999), Science consists of physical, chemical and biological concepts, thus an integration is required to establish the connections among these concepts.

According to Nietzsche \& Wilson (1965), the reason why the energy terms are different from those of the others is either those energy terms are so abstract as in the storage of solar energy, the photosynthesis, or they are clear enough to understand through only simple observations such as the turbines which work by means of transforming the potential energy of water into kinetic energy (Dumanoğlu, 1997: 28). Ellse (1998) stated that potential and kinetic energy are the most commonly taught concepts in Science teaching, yet other forms of energy should also be emphasized in teaching energy. Many studies show that integration and establishing connections increase learning and success.

In this study, the subjects "Work, Power, Energy and Simple Machines" were taught with activities which are in compliance with the constructivist approach. The subjects related to energy which carries interdisciplinary qualities in Physics, Chemistry and Biology were handled in connection with one another, and students were asked to configure the concepts of "transformation of energy" and "preservation of energy" meaningfully in their minds. The research question can be expressed as follows: "Does the interdisciplinary Science teaching based upon constructivist approach have any effects on the achievement of students and their attitudes towards Science?" By providing an interactive atmosphere based upon constructivist approach, this study aims to investigate the effects on students' learning 
levels by the activities, which involve active participation of students, and are designed according to the Science curriculum and interdisciplinary teaching that is based upon constructivist approach, then the results to the learning level of the group of students who are taught with traditional methods.

In this study, semi-experimental design with 'pre-test'- 'post-test' control group was employed. The research was conducted in an eight-week period of time in the spring term of 2004-2005 Academic Years. The research consists of two groups; the control group and the experimental group. The experimental group and control group consisting of 68 of pupils in the $7^{\text {th }}$ grade of a primary school in Buca/İzmir were selected according to their achievements in their lessons and the results of their pre-tests. The data of the research were collected by means of Science Lesson Achievement Test, and the Scale of Attitude towards Science.

The data obtained from the Achievement Test and the Attitude Scale, which were given to the experimental and control groups, were analyzed by operating SPSS 10.00 packet programme. The average achievement scores of students were calculated and comparisons were made between the control and the experimental groups by administering t-test, and then the obtained data were transferred into tables or charts. The tables and charts which were obtained from the responses of the Control and the Experiment group students to the achievement test and attitude test were presented in the sections of findings and comments.

It was found out that there was no significant difference between the scores that students in the control and the experimental group got from the 'Achievement Test' and 'pre-test' in the subject of "Work, Power, Energy and Simple Machines". The average score of the 'post-test' scores of the students in the experimental group, who were taught in compliance with the interdisciplinary constructivist approach was higher than those of the control group. The 'post-test achievement' also showed that there was a significant difference in favor of the Experiment group. According to the 'pre-test' results of the students in the control and the experimental group, there was no difference in their scores in Attitude towards the Science Lesson, whereas the result was in favor of the experimental group according to their 'postattitude' scores. These finding points out the fact that interdisciplinary teaching based upon constructivist approach affects the attitude towards the Science lesson positively. As for the experimental group, there was a positive and significant correlation between the scores of 'achievement posttest' and 'attitude post-test'. It can also be said that the interdisciplinary teaching, which takes constructivist approach as a base while studying the 
subjects "Work, Power, Energy and Simple Machines" in the 7th grade, increases the success of students in comparison with the traditional teaching methods.

It is thought that the success of students will increase if various teaching methods, in which the students are active and the teacher guides them, are employed instead of using traditional methods in teaching Science. The subjects of energy in the Science curriculum of primary schools should be handled in an integrative way. The students can establish the interdisciplinary correlation in Science lessons only if they grasp the importance of the integrity of the Science subjects. The teachers should take courses and undergo in-service training related to the subject, so that they can understand the importance of integrity and teach it to their students.

NOTE: This is an extended summary of the following article originally written in Turkish. 


\title{
Yapılandırmacı Yaklaşıma Göre Modellendirilmiş Disiplinler Arası Uygulama: Enerji Konularının Öğretimi
}

\begin{abstract}
Güliz AYDIN*
Ali Günay Balım*

ÖZ: Çalışmada, öğrencilerin 'İş, Güç, Enerji ve Basit Makineler' konularını anlamaları üzerine yapılandırmacı yaklaşım ile geleneksel yaklaşımın etkileri ortaya konulmaktadır. Disiplinler arası bir nitelik taşıyan enerji konularının öğrenilmesinde yapılandırmacı yaklaşımın uygulandığ 1 deney grubu ile geleneksel yaklaşımın uygulandığ kontrol grubu arasında bilişsel ve duyuşsal düzeylerde anlamlı bir fark olup olmadığ 1 araştırılmıştır. Araştırmada ön test-son test kontrol gruplu yarı deneysel desen kullanılmıştır. 2004-2005 öğretim yılının ikinci döneminde yapılan araştırmaya 68 yedinci sınıf öğrencisi katılmıştır. Öğrencilere öğretimden önce ve sonra Fen dersine yönelik tutum ölçeği ile 'İş, Güç, Enerji ve Basit Makineler' başarı testi uygulanmıştır. Uygulanan ön testler doğrultusunda, öğrencilerin Fen başarıları ve tutumları arasında başlangıçta anlamlı bir fark olmadığı, öğretimden sonra ise bilişsel ve duyuşsal düzeylerde deney grubunun lehine anlamlı farklar olduğu belirlenmiş̧ir.
\end{abstract}

Anahtar Sözcükler: Yapılandırmacı yaklaşım, disiplinler arası öğretim, enerji kavramı

\footnotetext{
*Fen Bilgisi öğretmeni.

** Yrd.Doç.Dr., Dokuz Eylül Üniversitesi, agunay.balim@deu.edu.tr
} 


\section{GİRIS}

Günümüzde eğitim, uygulamalı bir bilim dalı olarak gelişmekte ve Fen Bilimlerine dayalı olarak üretilen teknolojiler, ülkelerin gelişimlerine katkıda bulunmaktadır. Buna bağlı olarak, Fen eğitiminin önemi de gün geçtikçe artmaktadir.

Günümüz bireylerinden, bilgi üretmeleri beklenmektedir. Birey kendisine aktarılan bilgileri aynen kabul etmek yerine bilgiyi yorumlayarak, sorgulayarak ve araştırarak anlamın yaratılması sürecine etkin olarak katılmalıdır. Öğrenilen bilgilerin uygulanabilmesi, bilginin kalıcı olması açısından bir avantajdır. Günümüzde, öğrencilerin derslere aktif katılımlarına olanak sağlamayan öğretim yöntemlerini kullanmak yerine, öğrencileri mümkün olduğunca yapılan etkinliğin içine katmak eğitimciler tarafindan tercih edilmektedir (Yalvaç ve Sungur, 2000: 56).

Öğrencilerin bilişsel, duyuşsal ve devinişsel yeteneklerinin gelişmekte olduğu ilköğretim çağında bilgilerin veriliş tarzı çok önemlidir. İlköğretim, öğrencileri hayata hazırlayıcı, onlara doğal ve toplumsal çevre hakkında bilgi verici bir eğitim aşamasıdır (Yavru ve Gürdal, 1998: 327). İlköğretimde yer alan Fen dersleri, öğrencilerin ilgi alanlarının belirlenmesi ve yeteneklerinin ortaya çıkarılması açısından son derece önemlidir (Akgün, 2001). Öğrencilerin bilgiyle doldurulması gereken boş bir kap olarak görüldüğü geçmişteki eğitim anlayışının yerini, günümüzde öğrencilerin kendi öğrenmelerinden sorumlu tutuldukları, öğrenme sürecinde etkin olarak yer almaları gerektiğine inanılan eğitim anlayışı almaktadır (Tonbul, 2001: 16). Bu nedenle, bireylerin kendi bilgilerini kendilerinin oluşturarak daha iyi öğrendikleri yapılandırmacı öğrenme yaklaşımına uygun yöntemlerin kullanılması gerektiği düşünülmektedir.

İnsanların kendi deneyim ve düşüncelerinden gelen kendi bilgilerini inşa etmeleri kavramı, yapılandırmacılık olarak adlandırılır (Martin, 1997: 154). Gürol (2002: 162) öğrenmenin, eski bilgilerin yeni deneyimler ve yaşantıların 1şı̆̆ında yeniden yorumlanması ve oluşturulması ile gerçekleştiğini belirtmiştir. Öğretmen merkezli ve öğrencilerin pasif dinleyiciler oldukları geleneksel öğretim yöntemlerinin aksine yapılandırmacı model, öğrencinin öğrenmede çok aktif olması gerektiğini savunur. Bilginin her bir öğrenen tarafından bireysel olarak yapılandırıldığı, öğrencinin kendisine ulaşan bilgileri aynen almadığ 1 ve öğrenmede bireyin ön bilgilerinin, kişisel özelliklerinin ve öğrenme ortamının son derece önemli olduğu vurgulanmaktadır (Özmen, 2004). Richardson (1997: 3)'a göre, bireyler daha önceki bilgi ve inançlarına dayalı olarak yeni anlayışlarını kendileri yapılandırırlar. Kişi, daha önce bilmediği bir durumu 
anlamlandırmak için sadece var olan bilgilerini kullanabilir ve yeni öğrenmeler, dış dünyayla etkileşim sayesinde önceki bilgilerin üzerine inşa edilir (Gott \& Johnson, 1999: 23; Johnson \& Gott, 1997: 2).

Yapılandırma sürecinde birey, zihninde bilgiyle ilgili anlam oluşturmaya ve oluşturduğu anlamı kendisine mal etmeye çalışır. Diğer bir deyişle, bireyler öğrenmeyi kendilerine sunulan biçimiyle değil, zihinlerinde yapılandırdıkları biçimiyle oluştururlar (Yaşar, 1998: 69). Yapılandırmacı yaklaşım, öğrenci merkezlidir. Öğrenci merkezli öğretimde öğrenci, öğrenme sürecinde, yeni bilgileri zihninde yapılandırırken, önceki bilgilerini gözden geçirir; konu hakkında neyi bilip neyi bilmediğini belirler; yeni bilgiler kazanma aşamasında gözlem, deney, uygulama, araştırma ve inceleme gibi öğretim etkinliklerini kullanarak öğrenmesini sürekli olarak yapılandırır (Orhan ve Bozkurt, 2005: 124). Öğrenci merkezli öğretim denilince öğretmenin görevinin azaldığı düşünülmemelidir. Aksine yapılandırmacı yaklaşımda öğretmen daha araştırıcı olmalıdır (Köseoğlu ve Kavak, 2001: 144-145). Öğrencilerin öğrenme ortamına aktif katılımlarını teşvik etmek, ön bilgileriyle yeni bilgileri arasında ilişki kurmalarını sağlamak, kendi sorularını sormalarını desteklemek, deneylerini yürüterek sonuçlara ulaşmalarına rehberlik etmek, yapılandırmacı öğretmenin görevlerinden bazılarıdır (Orhan ve Bozkurt, 2005: 131). Ögrretmen, öğrencilerin çeşitli aktiviteleri yapmalarına ve sonuçları bulmalarına olanak sağlayarak onlara rehberlik etmeli, yeni bilgiyi anlamlı bir şekilde yapılandırmalarını sağlamalıdır (Martin, 1997: 157). Yapılandırmacı yaklaşıma dayalı çeşitli etkinlikler ve deneyler yaptırarak öğrencilerin yeni bilgilerini anlamlandırmalarına ve kavramları ilişkilendirmelerine yardımcı olmalıdır (Cansiz, 2002: 5).

Fen öğretiminde yer verilen etkinlikler, öğrencilerin merakını uyandırarak onların önceliklerini sorgulamalarına ve doğal olayları farklı yönlerden algılamalarına yol açar. Etkinliklerin çoğu, kavram yanılgılarını düzeltmeye yardımc1 olur (Kaptan ve Korkmaz, 2000: 25).

$\mathrm{Bu}$ çalışmada, öğrencilerin zihinsel becerilerini kullanarak bilgiyi yapılandırmalarını ve derslere aktif katılımlarını sağlayacak etkinlikler hazırlanarak, bilişsel ve sosyal yapılandırmacı yaklaşımı temel alan disiplinler arası öğretim yapılmıştır.

Disiplinler arası öğretim "disipliner konu alanlarının belirli kavramlar ya da temalar etrafinda anlamlı bir şekilde bir araya getirilerek sunulması" (Yıldırım, 1996) olarak tanımlanabilir. Disiplinler arası öğretimde amaç, hem seçilen konunun anlamlı bir bütün olarak öğrenilmesi, hem de öğrencilere aynı konunun farklı disiplinler açısından incelenmesi olanağının 
yaratılmasıdır (Yalçın ve Yıldırım, 1998: 147). Disiplinler arası öğretimde, belirli bir kavram, problem ya da konu temel alınarak, bu kavrama değişik yönlerden 1 şı tutabilecek bilgi ve beceriler ilgili alanlardan alınarak bütünleştirilir. Disiplinler arası bir düzenleme sayesinde hem belirli disiplinlere ait bilgi ve becerilerin öğrenilmesi, hem de bunların anlamlı bir şekilde bütünleştirilmesi mümkün olur.

Disiplinlere dayalı öğretimin bir sonucu olarak öğrenilen bilgilerin anlamsız olmaya başlaması, günlük hayattan kopuk olması, bilgi ve becerilerin soyut ve uygulanmasının güç olması gibi problemler ortaya çıkmaktadır (Yıldırım, 1996: 93). İlköğretim okullarında görev yapan Fen öğretmenlerinin, herhangi bir Fen kavramını verirken, bu kavramın Fizik, Kimya ve Biyoloji ile ilgili bölümlerini bir bütünlük içinde vermeleri gerekmektedir.

Fen öğretiminde neden bütünleștirme yapılması gerektiğini Gürdal, Şahin ve Bayram (1999: 384) şöyle açıklamışlardır:

1. Fen; fiziksel, kimyasal ve biyolojik kavramları içermektedir. Bu kavramlar arasında ilişkileri kurmak için bütünleştirme gereklidir. Anlamlı öğrenme için bu şarttır.

2. Bütünleştirilmiş öğretim, Fen Bilimlerindeki olayları bir bütün içinde açıklamayı kolaylaştırır.

3. Bütünleştirilmiş öğretim, öğrenmeyi olumlu yönde etkilemektedir.

Kirwan (1985), pek çok öğretmenin enerji konularını öğretmekte zorlandıklarını belirtmiştir. Fen derslerinde enerji ile ilgili kavramların öğretilmesinde birçok güçlükle karşılaşılmakta, Fen öğretim programları incelendiğinde, enerji ile ilgili olarak en kolay anlatılan ve anlaşılan enerji kavramlarının potansiyel ve kinetik enerjiler olduğu ancak enerji kavramları arasındaki ilişkinin belli bir sıraya konulmadığ 1 görülmektedir (Ellse, 1988; Dumanoğlu, 1997: 6). Lin \& Hu (2003), beş okuldan 106 yedinci sınıf öğrencisi ile yaptıkları çalışmada, öğrencilerin enerji akış1 ve madde döngüsü konularındaki kavramalarını belirlemişlerdir. Sonuçlar, öğrencilerin çoğunun enerji akışı ve madde döngüsü konuları ile ilgili kavramlar arasındaki ilişkileri kurmakta başarısız olduklarını göstermiştir.

Nitschke \& Wilson (1965)'a göre enerji kavramlarının diğer kavramlardan farklı olmasının sebebi, ya fotosentez olayında güneş enerjisinin depolanmasında olduğu gibi çok soyut olması, ya da suyun potansiyel enerjisinin kinetik enerjiye dönüştürülerek türbin çalıştırılması uygulamasında olduğu gibi basit gözlemlerle anlaşılacak kadar açık olmasından ileri gelmektedir (Dumanoğlu, 1997: 28). Ellse (1988), Fen 
öğretiminde yaygın olarak potansiyel ve kinetik enerjilerin öğretimine yer verildiğini, enerji öğretiminde diğer enerji formlarının da yer alması gerektiğini ifade etmiştir. Ogborn (1990)'a göre, öğrenciler ve öğretmenler enerjiyi değişimin nedeni olarak düşünmekte; öğrenciler enerjiyi, canlı olmakla sahip olunan hayati bir olay olarak görmekte, enerji, aktivite, eylem, güç, kuvvet gibi sözcükleri birbirinin yerine kullanmaktadırlar.

Çeşitli araştırmalar, bütünleştirme ve ilişki kurmanın derinlemesine öğrenmeyi ve başarıyı arttırdığını göstermektedir. Gürdal, Şahin ve Bayram (1999) ilköğretim 4. ve 5. sınıflarla yapmış oldukları araştırmada, Fen öğretiminde bütünleştirmenin, öğrenci başarılarını geleneksel öğretime göre daha fazla artırdığı sonucuna varmışlardır.

$\mathrm{Bu}$ çalışmada, "İş, Güç, Enerji ve Basit Makineler" konuları yapılandırmacı yaklaşıma uygun etkinliklerle öğretilmeye çalışılmış ve disiplinler arası bir nitelik taşıyan enerji konuları, Fizik, Kimya ve Biyoloji alanlarında birbiriyle ilişkili ele alınmış, 'enerji dönüşümü' ve 'enerji korunumu' kavramlarını öğrencilerin zihinlerinde anlamlı bir şekilde yapılandırabilmeleri sağlanmaya çalışılmıştır. "İş, Güç, Enerji ve Basit Makineler" konularıyla ilgili kavram ve ilkelerin öğrencilerce doğru bir şekilde yapılandırılması, ilerleyen yıllarda bu kavram ve ilkelerle ilgili üst kavram ve ilkelerin daha iyi yapılandırılmasını ve öğrencilerin bu konularda daha az kavram yanılgılarına sahip olmalarını sağlayacaktır.

$\mathrm{Bu}$ araştırmanın problemi, "Yapılandırmacı yaklaşıma dayalı disiplinler arası Fen öğretiminin, öğrencilerin Fen başarıları ve Fene yönelik tutumları üzerinde etkileri var mıdır?" şeklinde ifade edilebilir. Bu problem cümlesine bağlı olarak araştırmanın alt problemleri şunlardır:

1. Yapılandırmacı yaklaşıma dayalı disiplinler arası Fen öğretiminin uygulandığı deney grubundaki öğrenciler ile geleneksel öğrenme yaklaşımının uygulandığı kontrol grubundaki öğrencilerin akademik başarıları arasında anlamlı bir fark var mıdır?

2. Deney ve kontrol gruplarındaki öğrencilerin Fen dersine yönelik tutumları arasında anlamlı bir fark var midir?

3. Her iki gruptaki öğrencilerin akademik başarıları ile Fen dersine yönelik tutum puanları arasında anlamlı bir ilişki var mı dır?

Çalışmanın amacı, yapılandırmacı yaklaşıma dayalı etkileşimli bir ortam sağlayarak; Fen öğretim programına ve yapılandırmacı yaklaşımı temel alan disiplinler arası öğretime uygun olarak hazırlanmış, öğrencilerin pasif durumdan aktif duruma geçmelerini sağlayacak etkinliklerin 
öğrencilerin öğrenme düzeylerine etkisini araştırarak geleneksel yaklaşımla ders sunulan grubun öğrenme düzeyiyle karşılaştırmaktır.

\section{YÖNTEM}

$\mathrm{Bu}$ araştırmada "ön test-son test kontrol gruplu yarı deneysel desen" kullanılmıştır. Ön test-son test kontrol gruplu desende, yansız atama ile oluşturulmuş iki grup bulunmakta olup bunlardan biri deney diğeri kontrol grubudur. Her iki grupta da deney öncesi ve deney sonrası ölçmeler yapılmaktadır (Karasar, 2000).

Araştırma deneysel bir çalışma olduğu için, örneklem seçimi yerine çalışma grupları alınmış ve uygulanan başarı testi ile Fen dersine yönelik tutum ölçeğinden elde edilen ön test sonuçlarına göre bu grupların eşitliği üzerinde durulmuştur. Deneysel araştırmalarda, örneklemin amaca uygunluğuna bakılmalıdır (Büyüköztürk, 2001: 5).

Araştırma, 2004-2005 öğretim yılının ikinci döneminde, 8 haftalık bir sürede gerçekleştirilmiştir. Araştırma grubunu, İzmir ili Buca ilçesi Süleyman Bilgen İlköğretim Okulu'nda ön test sonuçlarına ve öğrencilerin derslerdeki başarılarına bakılarak seçilmiş biri deney, diğeri kontrol grubu olan 7A ve 7C şubelerinde okuyan 68 (deney grubundan 34, kontrol grubundan 34) öğrenci oluşturmaktadır. Deney ve kontrol gruplarında aynı öğretmen öğretim yapmıştır.

Veri Toplama Araçları

$\mathrm{Bu}$ araştırmada veriler, Fen Bilgisi başarı testi ve Fene Yönelik Tutum Ölçeği ile toplanmıştır.

\section{Fen Bilgisi Dersi Başarı Testi}

Hazırlanan Fen Bilgisi Başarı Testi, ilköğretim 7. sınıfta işlenen "İş, Güç, Enerji ve Basit Makineler" konularını kapsayan çoktan seçmeli sorulardan oluşmuştur. Testi geliştirme aşamasında, kapsam geçerliği için ilköğretim Fen Bilgisi Öğretim Programı (2000) temel alınarak belirtke tablosu hazırlanmıştır.

Testin kapsam geçerliği için uzman görüşüne başvurulmuş ve öneriler doğrultusunda gerekli değişiklikler yapılarak, kapsam geçerliği sağlanmaya çalışılmıştır. Testin görünüş geçerliği için de uzman görüşü alınmıştır.

Başarı testini geliştirme aşamasındaki ön uygulamalar, daha önce bu ünitenin konularını öğrenmiş olan bir üst sınıf öğrencileri üzerinde gerçekleştirilmiştir. Başlangıçta 40 maddelik olan test, 142 sekizinci sınıf 
öğrencisine uygulanmıştır. Ön deneme sonucunda testin KR-20 güvenirlik katsayısı 0,78 olarak bulunmuştur.

Ön uygulama sonrasinda yapllan madde analizi sonucunda testte yer alan 15 soru, ayırt edicilik indeksleri 0,30'dan küçük olduğu için testten çıkarılmuştır. Testin ön uygulanmasından sonra yapılan madde analizi sonucunda, bilişsel alanın bilgi düzeyindeki 2 soru, kavrama düzeyindeki 5 soru, uygulama düzeyindeki 5 soru ve analiz düzeyindeki 3 soru testten çıkarılmıştır. Bunun sonucunda geliştirilen test, 4 bilgi, 7 kavrama, 10 uygulama ve 4 analiz düzeyinde soruyu içermektedir. Ön uygulamadan sonra testten çıkarllan sorular, testin kapsam geçerliğini bozacak nitelikte değildir. Testin son hali 25 tane çoktan seçmeli soru içermektedir.

Farklı başarı düzeylerini ayırt etmek ve öğrencileri öğrenme derecelerine göre sıralamak için hazırlanan bir başarı testinin ortalama güçlüğünün 0,50 civarında olması istenir. Bunun nedeni, bu güçlükteki bir testin daha güvenilir ve daha ayırt edici olmasıdır. Testin ortalama güçlüğü 0,50'den küçükse test öğrencilere güç gelmiştir; 0,50 'den büyükse kolay gelmiştir (Tekin, 2003: 102). Öğrencilerin, 40 sorunun ortalama 18,03'ünü cevaplandırdıkları görülmüş ve soruların cevaplanma yüzdesi yani testin ortalama güçlüğü 0,45 olarak bulunmuştur.

$\mathrm{Bu}$ başarı testinin kullanılma amacı, öğrencilerin "İş, Güç, Enerji ve Basit Makineler" konularıla ilgili bilgilerini ön test ve son test şeklinde yoklayarak, uygulanan yöntemlerden kaynaklanabilecek bilişsel düzeydeki gruplar arası farklılıkları ortaya çıkarmaktır.

\section{Fen Bilgisi Dersine Yönelik Tutum Ölçeği}

Bir derse veya konuya karşı olumlu tutum, karşıllk verme isteği gösterme, karş1lık vermekten tatmin duyma, olumlu bir yönü, bir değeri olduğunu kabullenme ve bir değer olarak kabulüne taraftar olma şeklindeki davranışları içerir (Özçelik, 1992: 109).

Bu çalışmada, Geban ve arkadaşları (1994) tarafından öğrencilerin Fen dersine yönelik tutumlarını ölçmek amacıyla geliştirilmiş, 15 maddeden oluşan ve güvenirliği 0,83 olarak bulunmuş olan 5'li Likert tipi Fen Dersine Yönelik Tutum Ölçeği değişiklik yapılmadan kullanılmıştır.

Tutum ölçeği deney ve kontrol gruplarına uygulamadan önce ön test, uygulamadan sonra ise son test olarak verilmiştir. Bu ölçek, uygulama başlamadan önce her iki grubun Fen dersine yönelik tutumlarının denk olup olmadığını, uygulama sonrasında ise deney ve kontrol gruplarında uygulanan farklı yöntemlerin öğrencilerin Fen dersine yönelik tutumlarına etkisini karşılaştırmak amacıyla kullanılmıştır. 
Deneysel uygulamadan önce veri toplama araçları hazırlanmıș ve geliştirilmiştir. Fen öğretim programındaki kazanımlara uygun öğretim malzemeleri ve ders planları hazırlanmıştır. Aynı okulda yer alan ve derslerine aynı Fen öğretmeninin girdiği iki 7. sınıf şubesi deney ve kontrol grubu olarak belirlenmiştir. Çalışmalar sürdürülürken okulun haftalık ders programında yer alan Fen ders saati sürelerine (haftada 3 ders saati) uyulmuş; deney grubunda sosyal yapılandırmacı yaklaşıma uygun olan etkinlikler yapılarak, kontrol grubunda ise düz anlatım, soru-cevap gibi geleneksel öğretim teknikleri kullanılarak dersler işlenmiştir. Toplam 8 haftalık bir sürede gerçekleştirilen çalışmanın ilk haftası ön testler uygulanmış, 6 hafta süren deneysel uygulamadan sonraki hafta ise son testler uygulanmiştır.

Deney grubundaki öğrenciler, ders öğretmeninin yardımıyla başarı durumlarına bakılarak heterojen gruplar oluşturacak şekilde 5'er kişilik gruplara ayrılmıştır. Enerji türlerini, enerji korunumunu ve enerji dönüşümlerini, öğrencilerin zihinlerinde anlamlı bir şekilde yapılandırmalarını sağlayacak olan etkinlikler grup çalışmaları şeklinde yapılmış, bütün grupların aynı anda, aynı etkinlikleri yapmaları sağlanmıştır. Böylece öğrencilerin hem konulara ilişkin bilişsel alan becerilerini, hem grup çalışmaları sayesinde duyuşsal alan becerilerini, hem de deneysel etkinlikler sayesinde devinişsel alana yönelik becerilerini geliştirmeleri amaçlanmıştır.

Araştırmada, deney grubunda kullanılmak üzere " İş, Güç, Enerji ve Basit Makineler " konuları ile ilgili olarak yarı açık uçlu 23 deney, 2 anlam çözümleme tablosu, 1 kavram haritası, 2 Cd gösterimi (1.'si iş, iş-enerji ilişkisi, enerji dönüşümleri ve basit makinelerle ilgili; 2.'si besinler, fotosentez ve solunumla ilgili), enerji dönüşümleri ile ilgili 2 levha ve her derste öğrencilerin deney vb. etkinlikleri grup arkadaşlarıyla yapabilmeleri için çok sayıda çalışma yaprakları hazırlanmıştır.

Deney grubunda yer alan öğrenci gruplarının, derslerde etkinliklere yönelik çalışma yapraklarında yer alan basamakları izleyerek uygun araçgereçleri kullanmaları, ilgili deney düzeneklerini oluşturmaları ve çalışma yapraklarında yer alan soruları önce grup arkadaşlarıyla yanıtlamaları, daha sonra ise sınıf tartışması şeklinde öğrencilerin sorulara yanıtlar vermeleri sağlanmıştır.

"Günlük yaşantımızdaki faaliyetlerimizi -yürümek, top oynamak vb.sürdürmek için neye ihtiyaç duyarız?", " Günlük faaliyetlerimizi sürdürmek için gerekli olan şeyi nelerden sağlarız?", "Yeryüzündeki bütün enerjilerin kaynağı nedir?", "Bildiğiniz enerji türlerini sayar mısınız?", "Bir odunun 
sobada yanması sırasında hangi enerji dönüşümü gerçekleşir?", "Bir tahtaya çekiçle çivi çakarken çivinin başının ısınmasının nedeni nedir?", "Pil, ampul ve anahtardan oluşan basit bir elektrik devresinde anahtar kapatıldığı ve böylece akım geçtiği zaman hangi enerji dönüşümleri gerçekleşir?” vb. sorular sorularak öğrencilerin dikkatleri çekilmiş; beyin fırtınası tekniği ile öğrencilerin yanıtları tartışılmış ve bu sorular sayesinde öğrencilerin bilgilerini nasıl yapılandırdıkları, bu konulara ilişkin ön bilgileri, yapılandırmacı yaklaşımı destekleyen bir örüntü içerisinde ortaya çıkarılmaya çalışılmıştır.

Güneşteki nükleer tepkimeler sonucu ortaya çıkan çok fazla miktardaki enerjinin bir kısmının uzayda ışık șeklinde ilerlediği, bitkilerin fotosentez yapmak için klorofilleri sayesinde Güneş 1şığını kullanarak ürettikleri besinlerin bir kısmını büyümek için kullandıkları, bir kısmını ise kimyasal enerjiye dönüştürerek depoladıkları, bitki örneğin bir insan tarafından yenildiğinde insanların kendi kimyasal enerji stoklarını oluşturdukları, kimyasal enerjinin bir kısmı nefes alma ve hareket etme gibi vücut işlevleri için kullanılırken (kinetik enerji), bir kısmının vücut ısısına dönüştüğü, yine örneğin bir çalar saati kurarken kullanılan kinetik enerjinin, saatin yayında şekil değiştirme enerjisine dönüştüğü, enerjinin bir kısmının saatin hareketli parçalarındaki sürtünmeden dolayı 1sı enerjisine dönüştügü, alarm çaldığında şekil değiştirme enerjisinin tokmakta mekanik enerjiye dönüştügü̈, zilin titreşimlerinin ses enerjisini ürettiği, enerjinin bir kısmının yine sürtünmeden dolay1 1s1 enerjisine dönüştüğü vb. ilişkilerin kurulmasını sağlayacak etkinlikler yapılması sağlanmıştır. Yapılan etkinlikler ve sınıf içi tartışmalarda enerji konuları, fiziksel, kimyasal ve biyolojik olarak disiplinler arası bir bakış açısıyla ele alınmıştır. Yapılan etkinliklerden sonra, enerji dönüşümü örnekleri içeren levhalar üzerinde, yapılan etkinliklerden elde edilen sonuçlardan da yararlanılarak bu enerji dönüşümlerinin nasıl gerçekleştiği tartışılmıştır. Bu şekilde, grupların yaptıkları etkinlikler sonucu enerji konularını zihinlerinde disiplinler arası bir anlayışla yapılandırıp yapılandıramadıkları anlaşılmaya çalışılmıştır.

Her bir gruba, satırlarında 'birbirine sürtülen buz kalıplarının erimesi', 'yakılan kömür sobasının odayı 1sıtması', 'buhar türbininin dönmesi' gibi çeşitli durumların, sütunlarında ise enerji dönüşümlerinin yer aldığı anlam çözümleme tablosu verilmiş, hangi enerji dönüşümlerinin gerçekleştiğini grup arkadaşlarıyla tartışarak, öğrencilerin bu tabloyu doldurmaları istenmiştir. $\mathrm{Bu}$ anlam çözümleme tabloları toplanarak öğrencilerin enerji dönüşümlerini kavrayıp kavramadıkları incelenmiştir. Ayrıca öğrenci gruplarına enerji ve ilişkili olduğu kavramları içeren "İş, Güç, Enerji ve Basit Makineler" konularıla ilgili tamamlanmamış bir kavram haritası 
verilerek bu kavram haritasının tamamlanması istenmiştir. Daha sonra her öğrenci grubunun çalışma yaprakları toplanarak sınıf içi tartışmalarla değerlendirilmiş, değerlendirilen çalışma yaprakları gruplara teslim edilerek geri dönütler verilmiştir. Tespit edilmiş olan eksiklikleri gidermeye yönelik olarak çalışmalar ve sınıf tartışmaları yapılmıştır.

\section{Veri Çözümleme Teknikleri}

Deney ve kontrol gruplarına ön test ve son test olarak uygulanan başarı testinden tutum ölçeğinden elde edilen veriler SPSS 10.00 paket programı kullanılarak çözümlenmiş, bu programda öğrencilerin başarı puan ortalamaları hesaplanıp t-testi kullanılarak deney ve kontrol grubu arasında karşılaştırmalar yapılmış ve elde edilen veriler tablolaştırılmıştır. Karşılaştırmalar 0,05 anlamlılık düzeyinde yapılmıştır.

Deney ve kontrol gruplarının son test başarı testi ile son test tutum testinden aldıkları puanlar arasında anlamlı bir ilişki olup olmadığ Momentler Çarpımı Korelasyon Katsayısı hesaplanarak 0,05 anlamlılık düzeyinde test edilmiştir.

\section{BULGULAR VE YORUMLAR}

$\mathrm{Bu}$ bölümde, deney ve kontrol gruplarının başarı testi ve tutum ölçeğinde yer alan sorulara verdikleri cevaplardan elde edilen veriler tablolar halinde sunulmuştur.

Tablo 1, deney ve kontrol gruplarına başlangıçta uygulanan ön başarı testlerinin puan ortalamalarını ve t-testi analiz sonuçlarını göstermektedir.

Tablo 1: Deney ve Kontrol Gruplarının Ön Test Başarı Puanlarının Karşılaştırılması

\begin{tabular}{llllllc}
\hline Grup & $N$ & $\begin{array}{l}\text { Aritmetik } \\
\text { Ortalama }\end{array}$ & $\begin{array}{l}\text { Standart } \\
\text { Sapma }\end{array}$ & t-değeri & $p$ & $\begin{array}{l}\text { Anlamlilk } \\
\text { Düzeyi }\end{array}$ \\
\hline Deney & 34 & 6,94 & 2,61 & 0,143 & 0,887 & $\mathrm{p}>0,05$ \\
Kontrol & 34 & 6,85 & 2,49 & & & \\
\hline
\end{tabular}

Tablo 1'deki ön test başarı ortalamaları incelendiğinde, deney grubunun puan ortalamasının 6,94; kontrol grubunun puan ortalamasının ise 6,85 olduğu görülmektedir. Ortalamaların birbirine oldukça yakın değerlerde olduğu ve yapılan analizler sonucunda gruplar arasında istatistiki anlamda bir farkın olmadığı belirlenmiştir. 
Tablo 2, deney ve kontrol gruplarının son test başarı puan ortalamalarını göstermektedir.

Tablo 2: Deney ve Kontrol Gruplarının Son Test Başarı Puanların Karşılaştırılması

\begin{tabular}{lllllll}
\hline Grup & $N$ & $\begin{array}{l}\text { Aritmetik } \\
\text { Ortalama }\end{array}$ & $\begin{array}{l}\text { Standart } \\
\text { Sapma }\end{array}$ & t-değeri & $p$ & $\begin{array}{l}\text { Anlamlllk } \\
\text { Düzeyi }\end{array}$ \\
\hline Deney & 34 & 16,26 & 3,24 & 9,698 & 0,000 & $\mathrm{p}<0,05$ \\
Kontrol & 34 & 9,29 & 2,65 & & & \\
\hline
\end{tabular}

Tablo 2'de görüldüğü gibi, deney grubunun puan ortalamas1 16,26; kontrol grubunun puan ortalamas1 ise 9,29'dur. Deney grubu ve kontrol grubuna ait ortalamalar arasındaki matematiksel farkın istatistiksel olarak da anlamlı olup olmadığını test etmek için yapılan t-testi analiz sonucunda anlamlı bir fark saptanmıştır. Bu değere göre, deney ve kontrol grubunun başarı ortalamaları arasındaki farkın anlamlı olduğu ve yapılandırmacı yaklaşımı temele alan disiplinler arası öğretime uygun olarak hazırlanmış uygulamaların öğrencilerin başarıları üzerinde olumlu etkiler yarattığı söylenebilir.

Tablo 1 ve 2'de görüldüğü gibi deney ve kontrol gruplarındaki öğrencilerin uygulama öncesindeki başarı düzeyleri, uygulamadan sonra artmıştır. Fakat, ön test başarıları arasında anlamlı bir farklılık olmayan iki gruptan deney grubunun, kontrol grubuna göre son testte daha başarılı olduğu saptanmıştır.

Uygulamadan önce verilen tutum ölçeği puanlarının t-testi ile karşılaştırılmasından elde edilen sonuçlar tablo 3 'te verilmiştir.

Tablo 3: Deney ve Kontrol Gruplarının Ön Test Tutum Puanların Karşılaştırılması

\begin{tabular}{llllclc}
\hline Grup & $N$ & $\begin{array}{l}\text { Aritmetik } \\
\text { Ortalama }\end{array}$ & $\begin{array}{l}\text { Standart } \\
\text { Sapma }\end{array}$ & t-değeri & $p$ & $\begin{array}{l}\text { Anlamlillk } \\
\text { Düzeyi }\end{array}$ \\
\hline Deney & 34 & 57,59 & 7,18 & 0,567 & 0,573 & $\mathrm{p}>0,05$ \\
Kontrol & 34 & 56,29 & 11,21 & & & \\
\hline
\end{tabular}


Tablo 3'te görüldüğü gibi, deney grubunun ön tutum ortalamas1 57,59; kontrol grubunun ön tutum ortalamas1 56,29'dur. Tabloya göre, deney ve kontrol gruplarının ön test tutum puanları arasında istatistiksel olarak anlamlı bir fark olmadığı saptanmıştır.

Uygulamadan sonra yeniden verilen tutum ölçeği puanlarının t-testi ile karşılaştırılmasından elde edilen sonuçlar tablo 4'de verilmiştir.

Tablo 4: Deney ve Kontrol Gruplarının Son Test Tutum Puanların Karşılaştırılması

\begin{tabular}{|c|c|c|c|c|c|c|}
\hline Grup & $N$ & $\begin{array}{l}\text { Aritmetik } \\
\text { Ortalama }\end{array}$ & $\begin{array}{l}\text { Standart } \\
\text { Sapma }\end{array}$ & $t$-değgeri & $p$ & $\begin{array}{l}\text { Anlamlılık } \\
\text { Düzeyi }\end{array}$ \\
\hline Deney & 34 & 66,17 & 6,90 & 4,598 & 0,000 & $\mathrm{p}<0,05$ \\
\hline Kontrol & 34 & 58,03 & 9,68 & & & \\
\hline
\end{tabular}

Tablo 4'te görüldüğ̈̈ gibi, uygulamadan sonra deney grubundaki öğrencilerin tutum puan ortalamaları 66,17; kontrol grubundaki öğrencilerin tutum puan ortalamaları 58,03'tür. Deney ve kontrol gruplarının tutum puanları arasında deney grubu lehine anlamlı bir fark olduğu saptanmıştır. Deney grubu ögrencilerinin Fen dersine yönelik tutumlarında, kontrol grubu öğrencilerine göre anlamlı bir gelişme sağlanmıştır.

Deney grubundaki öğrencilerin ön test ve son test tutum puanlarının ortalamaları ile kontrol grubundaki öğrencilerin ön test ve son test tutum puanlarının ortalamaları karşılaştırılmış, çıkan sonuçlar tablo 5'te verilmiştir.

Tablo 5: Deney ve Kontrol Gruplarının Ön Test-Son Test Tutum Puanlarının Karşılaștırılması

\begin{tabular}{|c|c|c|c|c|c|c|c|}
\hline Grup & Test & $N$ & $\begin{array}{l}\text { Aritmetik } \\
\text { Ortalama }\end{array}$ & $\begin{array}{l}\text { Standart } \\
\text { Sapma }\end{array}$ & t-değeri & $p$ & $\begin{array}{l}\text { Anlamlılık } \\
\text { Düzeyi }\end{array}$ \\
\hline \multirow{4}{*}{ Deney } & Ön & & & & \multirow{4}{*}{$-4,991$} & \multirow{4}{*}{0,000} & \multirow{4}{*}{$\mathrm{p}<0,05$} \\
\hline & Test & 34 & 57,59 & 7,18 & & & \\
\hline & Son & & & & & & \\
\hline & Test & 34 & 66,17 & 6,90 & & & \\
\hline \multirow{4}{*}{ Kontrol } & Ön & & & & \multirow{4}{*}{0,788} & \multirow{4}{*}{0,436} & \multirow{4}{*}{$\mathrm{p}>0,05$} \\
\hline & Test & 34 & 56,29 & 11,21 & & & \\
\hline & Son & & & & & & \\
\hline & Test & 34 & 58,03 & 9,68 & & & \\
\hline
\end{tabular}


Tablo 5'e göre, deney grubunun son test tutum puanlariyla ön test tutum puanları arasında istatistiksel olarak anlamlı bir farklılık olduğu saptanmıştır. Deney grubundaki öğrencilerin Fen dersine yönelik tutum puanlarının ortalaması uygulamadan sonra artmıştır. Kontrol grubundaki öğrencilerin de uygulamadan sonra Fen dersine yönelik tutum puanlarının ortalamasında bir artma olduğu halde, bu artış istatistiksel olarak anlamlı bulunmamıştır.

Öğrencilerin akademik başarıları ile Fen dersine yönelik tutum puanları arasında anlamlı bir ilişkinin olup olmadığı Pearson Momentler Çarpımı Korelasyon Katsayısı hesaplanarak bulunmuştur.

Tablo 6, deney ve kontrol gruplarındaki öğrencilerin son başarı testi puanları ile son tutum puanları arasındaki ilişkiyi göstermektedir.

Tablo 6: Deney ve Kontrol Gruplarının Başarı Testi Puanları ile Tutum Puanları Arasındaki İlișki

\begin{tabular}{clcc}
\hline Gruplar & & $r$ & $p$ \\
\hline \multirow{2}{*}{ Deney } & Son Başarı Testi Puanları & 0,414 & 0,015 \\
& Son Tutum Puanları & & \\
\multirow{2}{*}{ Kontrol } & Son Başarı Testi Puanları & 0,207 & 0,239 \\
& Son Tutum Puanları & & \\
\hline
\end{tabular}

Tablo 6 incelendiğinde, deney grubu öğrencilerinin son test başarı puanları ile son test tutum puanları arasında orta düzeyde, pozitif ve anlamlı bir ilişki olduğu görülmektedir $(\mathrm{r}=0,414 ; \mathrm{p}<0,05)$. Buna göre, son başarı testinden yüksek puan alan öğrencilerin Fen dersine yönelik tutumlarının da olumlu olduğu söylenebilir.

Tablo 6'ya göre, kontrol grubu öğrencilerinin son test başarı puanları ile son test tutum puanları arasında düşük düzeyde, pozitif bir ilişki vardır $(\mathrm{r}=0,207 ; \mathrm{p}>0,05)$. Bu durum, kontrol grubundaki öğrencilerin son test başarı puanları artmış olsa bile, tutum puanlarının fazla değişmemesi şeklinde açıklanabilir.

\section{TARTIŞMA VE SONUÇ}

Yapılandırmacı yaklaşıma dayalı disiplinler arası öğretim yapılan deney grubundaki öğrencilerin "İş, Güç, Enerji ve Basit Makineler" başarı testinden aldıkları son test puanların ortalaması, geleneksel yaklaşımla öğretim yapılan kontrol grubundaki öğrencilerin aynı testten aldıkları puanların 
ortalamasından yüksek çıkmıştır. Ortalamalar arasında 0,05 düzeyinde anlamlı çıkan bu fark, başarı testi sonuçlarına göre, deney grubu öğrencilerinin kontrol grubu öğrencilerine göre daha başarılı olduklarını göstermektedir. Deney ve kontrol gruplarının her ikisinde de başarı testi sonuçlarına göre öğretim sonrasında başarı düzeylerinde bir yükselme saptanmıştır. Fakat başarı düzeyindeki bu artış, deney grubunda daha fazladir.

Fen derslerinde Fizik, Kimya ve Biyoloji üniteleri içerisinde birbirinden kopuk ve farklı birer konuymuş gibi ele alınan enerji kavramı ile ilgili konular, bu çalışmada birbiriyle bağlantılı olarak ele alınmış, yapılan etkinliklerle öğrencilerin 'enerji korunumu', 'enerji dönüşümü' gibi kavramları anlamaları sağlanmaya çalışılmıştır. Enerji kavramının entegre bir şekilde verilmesinin enerji ve enerjiyle ilişkili diğer kavramların öğrenilmesine yardımcı olduğu görülmüştür. Deney grubu öğrencilerinin sorulara verdikleri cevapların doğruluk düzeyinin, kontrol grubuna göre daha yüksek olması bunu desteklemektedir.

Deney ve kontrol gruplarındaki öğrencilerin ön test sonuçlarına göre Fen dersine yönelik tutum puanlarında herhangi bir farklılık görülmezken, son tutum puanları arasında deney grubu lehine anlamlı bir farklılık vardır. Deney ve kontrol gruplarının son tutum puanları arasında anlamlı bir farkın olması, yapılandırmacı yaklaşıma dayalı disiplinler arası öğretimin Fen dersine yönelik tutumu olumlu yönde etkilediğini göstermektedir. Fen derslerini, grup çalışmaları şeklinde etkinlikler ve deneyler yaparak işleyen öğrencilerin Fen dersine yönelik tutumlarının, geleneksel öğretim ile ders yapılan öğrencilere göre daha olumlu olduğu belirlenmiştir.

Deney ve kontrol gruplarının kendi içerisinde son test başarı puanları ile son test tutum puanları arasındaki ilişki incelendiğinde, deney grubu öğrencilerinin başarı ile tutum puanları arasında pozitif ve anlamlı bir ilişkinin olduğu görülmektedir. Bu durumda, son başarı testinden yüksek puan alan deney grubu öğrencilerinin, Fen dersine yönelik tutumlarının da yüksek olduğu söylenebilir. Kontrol grubu öğrencilerinin son test başarı puanları ile son tutum puanları arasında düşük düzeyde, pozitif bir ilişkinin olduğu görülmektedir. $\mathrm{Bu}$ durumun, kontrol grubu öğrencilerinden son başarı testinden yüksek puan alan öğrencilerin başarı puanları artmış olsa da, tutum puanlarının değişmemesinden kaynaklandığı düşünülmektedir.

İlköğretim 7. sınıf düzeyinde, "İş, Güç, Enerji ve Basit Makineler" konuları işlenirken yapılandırmacı yaklaşımı temel alan disiplinler arası öğretimin (Fizik, Kimya ve Biyoloji ilişkili), öğrencilerin başarılarını geleneksel öğretime göre daha fazla artırdığ 1 söylenebilir. Bu, Gürdal, Şahin 
ve Bayram (1999)'ın ilköğretim 4. ve 5. sınıflarla enerji konularına ilişkin yapmış oldukları araştırmadan elde ettikleri, Fen öğretiminde bütünleştirmenin, öğrenci başarılarını geleneksel öğretime göre daha fazla artırdığı sonucunu destekler niteliktedir. Turgut (2001) da yaptığı çalışmada, yapılandırmacı öğretim yaklaşımı ile modellendirilmiş etkinliklerin öğrencilerin "İş, Güç, Enerji” konularında Fen başarılarına ve kavramsal gelişimlerine, geleneksel öğretim yaklaşımına göre daha fazla etki ettiği sonucuna varmıştır.

\section{ÖNERILER}

Yapılandırmacı yaklaşıma göre öğrenciler kendi bilgilerini kendileri oluşturduklarından, bilgiyi geleneksel öğretim yöntemleri ile doğrudan aktarmak yerine, ögrencilerin aktif oldukları, bilgilere kendilerinin ulaşmalarını sağlayan; yaparak, yaşayarak ve düşünerek öğrendikleri öğrenme ortamları oluşturulmalıdır.

Fen derslerinde disiplinler arası ilişkinin sağlanması, öğrencilerin Fen konuları arasında bütünleştirmeyi sağlamanın önemini kavramalarıyla olasıdır. Bunu sağlayacak olan öğretmenlerin entegre öğretimin önemini anlamaları ise, bu konuda verilecek hizmet içi seminer veya kurslarla mümkün olacaktır.

İlköğretim Fen programında bulunan enerji kavramları, bir bütünlük içinde ele alınarak düzenlenmelidir. Enerji kavramı ile ilgili konular, Fizik, Kimya ya da Biyoloji ile ilgili ünitelerde ayrı ayrı yer almamalı, bu konuyla ilgili bir ünite içerisinde, bir bütünlük içinde ele alınmalıdır.

Fen derslerinde, pahalı ve bulunması zor olan araç-gereçler yerine ulaşılması kolay olan malzemeler, basit ve ucuz araç-gereçler kullanılabilir. Derslerde geleneksel yöntemler yerine öğrencilerin aktif oldukları, öğretmenin ise onlara rehberlik ettiği çeşitli öğretim yöntemlerinin kullanılmasının öğrenci başarısını arttıracağı düşünülmektedir. 


\section{KAYNAKLAR:}

Akgün, Ş. (2001). Fen Bilgisi Öğretimi. Ankara: Pegem A Yayıncılık.

Büyüköztürk, Ş. (2001). Deneysel Desenler (1. Baskı). Ankara: Pegem A Yayıncilık.

Cansız, M. (2002). "Yapısalcı Öğrenme Yaklaşımıyla Model Kullanmanın Öğrencilerin Matematiğe Karşı Tutumlarına ve Genelleme Becerilerine Etkisi." Yayımlanmamış yüksek lisans tezi, Karadeniz Teknik Üniversitesi Fen Bilimleri Enstitüsü, Trabzon.

Dumanoğlu, F. (1997). “Ortaöğretimde Enerji Kavramının Öğretimi ve Enerji Eğitimi.” Yayımlanmamış yüksek lisans tezi, Karadeniz Teknik Üniversitesi Fen Bilimleri Enstitüsü, Trabzon.

Ellse, M. (1988). Transferring, not transforming energy. School Science Review, 69, 427-437.

Geban, Ö., Ertepınar, H., Yılmaz, G., Altın, A., ve Şahbaz, F. (1994). Bilgisayar Destekli Eğitimin Öğrencilerin Fen Bilgisi Başarılarına ve Fen Bilgisi İlgilerine Etkisi. I. Ulusal Fen Bilimleri Egitimi Sempozyuти: Bildiri Özetleri Kitabı, s:1-2, 9 Eylül Üniversitesi, İzmir.

Gott, R., Duggan, S. \& Johnson, P. (1999). What do practising applied scientist do and what are the implications for science education? Research in Science and Technological Education, 17, 97-107.

Gürdal, A., Şahin, F. ve Bayram, H. (1999). İlköğretim Öğretmen Adaylarının Enerji Konusunda Bütünlüğü Sağlama ve İlişki Kurma Düzeyleri Üzerine Bir Araştırma. Buca Eğitim Fakültesi Dergisi, 10, 382-395.

Gürol, M. (2002) Eğitim Teknolojisinde Yeni Paradigma: Oluşturmacılık. Firat Üniversitesi Sosyal Bilimler Dergisi, 12 (1), 159-183.

Johnson, P. \& Gott, R. (1997). Science in schools: Time to pause for thought? School Science Review, 81 (295), 21-28.

Kaptan, F. ve Korkmaz, H. (2000). Yapısalc1lik (Constructivism) Kuramı ve Fen Öğretimi. Çă̆daş Eğitim, 265, 22-27.

Karasar, N. (2000). Bilimsel Araştırma Yöntemi. Ankara: Nobel Yayın Dağıtım.

Kirwan, D. F. (1985). Energy Curricullum Development Guidelines. Science and Technology Education and Future Human Needs, 23-32. 
Köseoğlu, F. ve Kavak, N. (2001). Fen Öğretiminde Yapılandırıcı Yaklaşım. Gazi Üniversitesi Gazi Eğitim Fakültesi Dergisi, 21 (1), 139-148.

Lin, C. \& Hu, R. (2003). Students' Understanding of Energy Flow and Matter Cycling in the Context of the Food Chain, Photosynthesis and Respiration. International Journal of Science Education, 25 (12), 15291544.

Martin, D. J. (1997). Elementary science methods. A constructivist approach. Kennesaw State Collage. Delmar Publishers.

M.E.B. (2000). İlköğretim Okulu Fen Bilgisi Dersi (4,5,6,7,8. sınıf) Öğretim Programı. MEB Tebliğler Dergisi, 63, 2518, Kasım 2000.

Ogborn, J. (1990). Energy, change, difference and danger. School Science Review, 72 (259), 81-85.

Orhan, A. T. ve Bozkurt, O. (2005). İlköğretimde Fen ve Teknoloji Öğretimi, M. Aydoğdu ve T. Kesercioğlu (Ed.) Illköğretimde Fen ve Teknoloji Ĕgitiminde Yapılandirmacılık (Constructivism) (ss. 121-142). Ankara: Anı Yayıncılık.

Özçelik, D.A. (1992). Ölçme ve Değerlendirme, Ankara: ÖSYM Yayınları.

Özmen, H. (2004). Fen Öğretiminde Öğrenme Teorileri ve Teknoloji Destekli Yapılandırmacı (Constructivist) Öğrenme. The Turkish Online Journal of Educational Technology - TOJET January 2004 ISSN: 13036523 (1), Article 14. www.tojet.net/articles/3114.htm

Richardson, V. C. (1997). Constructivist teaching and teacher education: Theory and practice. Building New Understanding, London: Falmer Press, 3-14.

Tekin, H. (2003). Ĕgitimde Ölçme ve Değerlendirme (16. Baskı). Ankara: Yarg1 Yayınevi.

Tonbul, C. (2001). "İş̧irlikli Öğrenmenin İngilizce Dersine İlişkin Doyum, Hatırda Tutma Üzerindeki Etkileri ve İşbirlikli Öğrenme Uygulamalarıyla İlgili Öğrenci Görüşleri.” Yayımlanmamış yüksek lisans tezi, Dokuz Eylül Üniversitesi Eğitim Bilimleri Enstitüsü, İzmir.

Turgut, H. (2001). "Fen Bilgisi Öğretiminde Yapılandırmacı Öğretim Yaklaşımı ile Modellendirilmiş Etkinliklerin Öğrencide Kavramsal Gelişime ve Başarıya Etkisi." Yüksek lisans tezi, Marmara Üniversitesi Eğitim Bilimleri Enstitüsü, İstanbul. 
Yalçın, P. ve Yıldırım, H. (1998). "Disiplinler Arası Öğretim" Üzerine Bir Uygulama. Ç.Ü. Eğitim Fakültesi Dergisi, 17, 146-150.

Yalvaç, B. ve Sungur, S. (2000). Fen Bilgisi Öğretmen Adaylarının Laboratuvar Derslerine Karşı Tutumlarının İncelenmesi. D. E.Ü. Buca Eğitim Fakültesi Dergisi, 12, 56-64.

Yaşar, Ş. (1998). Yapısalcı Kuram ve Öğrenme-Öğretme Süreci. Anadolu Üniversitesi Ĕ̈itim Fakültesi Dergisi, 8 (2), 68-75.

Yavru, Ü. ve Gürdal, A. (1998). İlköğretim Okullarının 4. ve 5. Sınıflarında Laboratuvar Deneylerinin Öğrencilerin Mekanik Konusundaki Başarısına ve Kavramları Kazanmasına Etkisi. M.Ü. Atatürk Eğitim Fakültesi Eğitim Bilimleri Dergisi, 10, 327-338.

Yıldırım, A. (1996). Disiplinler Arası Öğretim Kavramı ve Programlar Açısından Doğurduğu Sonuçlar. Hacettepe Üniversitesi Ĕgitim Fakültesi Dergisi, 12, 89-94. 